\title{
Correction to "Temporal and Spatial variation of the surface winds in the Gulf of California"
}

\author{
S. G. Marinone, ${ }^{1}$ A. Parés-Sierra, ${ }^{1}$ R. Castro, ${ }^{2}$ and A. Mascarenhas ${ }^{3}$ \\ Received 23 March 2004; accepted 27 April 2004; published 26 May 2004.
}

[1] In the paper "Temporal and Spatial variation of the surface winds in the Gulf of California" by Parés-Sierra et al. [2003] (Geophys. Res. Lett., 30(6), 1312, doi:10.1029/ 2004GL016716) it was reported that the monsoon character of the winds over the Gulf of California was not apparent in QuikScat data. Their result was based on the climatological winds derived from an objectively analyzed, gridded, and temporally interpolated data constructed by Tang and Liu [1996] from QuikScat data. A re-analysis of the original data does show monsoonal winds over the Gulf of California. Therefore, the previous data base is not suited for marginal or local seas. INDEX TERMS: 3339 Meteorology and Atmospheric Dynamics: Ocean/ atmosphere interactions (0312, 4504); 3309 Meteorology and Atmospheric Dynamics: Climatology (1620); 4504 Oceanography: Physical: Air/sea interactions (0312). Citation: Marinone, S. G., A. Parés-Sierra, R. Castro, and A. Mascarenhas (2004), Correction to "Temporal and Spatial variation of the surface winds in the Gulf of California,' Geophys. Res. Lett., 31, L10305, doi:10.1029/ 2004GL020064.

\section{Introduction}

[2] For a long time it has been accepted that the winds over the Gulf of California are of monsoon character: from the NW during winter and from the SE during summer [e.g., Roden, 1958; Badan-Dangon et al., 1991; Douglas et al., 1993]. Recently Parés-Sierra et al. [2003] (PS from now on) found, using ftp://ftp-airsea.jpl.nasa.gov/pub/ www/DATA/QUICKSCAT/ from Tang and Liu [1996] (F1 from now on), that the monsoon does not exist. Their result is due to an annual mean wind from the NW that is larger than the seasonal amplitude. In this note we report that the result of PS, from the F1 data, is incorrect. Apparently the $\mathbf{F 1}$ data, obtained from (ftp://ftp. podaac.jpl.nasa.gov/pub/ocean_wind/quikscat/L3/data/) (F2 from now on) used a larger correlation scale than the width of the peninsula of $\mathrm{BC}$ (they do no report the scale), which contaminates the winds over the Gulf of California with information from the Pacific.

[3] The result caught the attention of the scientific community, because it challenged the historical idea of the monsoon. For this reason, we re-analyzed the data, going back to the original source (F2, the same used by Tang and Liu [1996]). The objective was to double-check

\footnotetext{
${ }^{1}$ Department of Physical Oceanography, CICESE, Ensenada, México.

${ }^{2}$ Facultad de Ciencias Marinas, UABC, Ensenada, México.

${ }^{3}$ Instituto de Investigaciones Oceanológicas, UABC, Ensenada, México.

Copyright 2004 by the American Geophysical Union. 0094-8276/04/2004GL020064\$05.00
}

our result and, if wrong, call the attention over the use of F1 in marginal seas or gulfs, where local effects are important, such as the Gulf of California where the winds are funneled by the mountains over the peninsula and mainland Mexico.

\section{Results and Conclusion}

[4] Using the $\mathbf{F 2}$ data, a climatology was constructed only where there are data, i.e., no spatial interpolation was done. Figure 1 shows the seasonal climatology averaged over the same 4 zones of the gulf used in PS $\left(29.5-32,28-29.5,26-28\right.$, and $\left.23-26^{\circ} \mathrm{N}\right)$. The figure shows both the results from F1 (same as Figure 5 in PS) and from F2. As can be observed, the winds do reverse during summer, i.e., the winds are up-gulf almost all summer.

[5] The messages of this note are that the monsoon does occur, and it is registered in the QuikScat data; however, the processed data by Tang and Liu [1996] should be used with care in coastal areas, marginal seas or gulfs, where the influence of the land is important in producing winds which do not follows the synoptic pattern. Objective analyses contaminates these local areas if a large scale
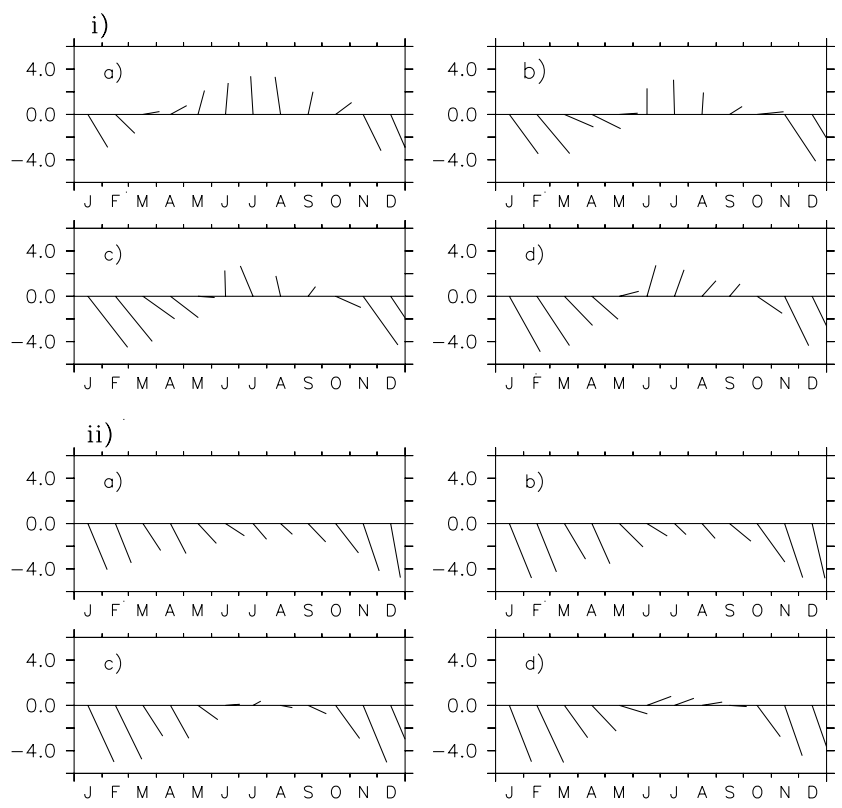

Figure 1. Monthly climatology of the surface winds average for the (a) Northern, (b) Island, (c) Central, and Southern regions of the Gulf of California from (i) this note and (ii) Parés-Sierra et al. [2003]. (Data from QuikScat: see text for details.) 
of influence is used, as is believed to be the case for the F1 data. Over large scales areas, like the whole ocean, the data are correct.

[6] Acknowledgment. The data was obtained from the NASA/ NOAA sponsored data system Seaflux, at JPL.

\section{References}

Badan-Dangon, A., C. E. Dorman, M. A. Merrifield, and C. D. Winant (1991), The lower atmosphere over the Gulf of California, J. Geophys. Res., 96, 16,877-16,896.

Douglas, M. W., R. A. Maddox, and K. Howard (1993), The Mexican Monsoon, J. Clim., 6, 1665-1677.
Parés-Sierra, A., A. Mascarenhas, S. G. Marinone, and R. Castro (2003), Temporal and spatial variations on the surface winds in the Gulf of California, Geophys. Res. Lett., 30(6), 1312, doi:10.1029/ 2002GL016716.

Roden, G. (1958), Oceanographic and meteorological aspects of the Gulf of California, Pacific Science, XII (1), January 21-45.

Tang, W., and W. T. Liu (1996), Objective interpolation of scatterometer winds, JPL Publ., 96-19, Jet Propultion Laboratory, Pasadena, CA.

R. Castro, Facultad de Ciencias Marinas, UABC, Ensenada, México.

S. G. Marinone and A. Parés-Sierra, Department of Physical Oceanography, CICESE, Ensenada, México. (marinone@cicese.mx)

A. Mascarenhas, Instituto de Investigaciones Oceanológicas, UABC, Ensenada, México. 